\author{
Mariola Tracz \\ Zakład Dydaktyki Geografii \\ Tomasz Rachwal \\ Zakład Przedsiębiorczości i Gospodarki Przestrzennej \\ Instytut Geografii \\ Uniwersytet Pedagogiczny im. Komisji Edukacji Narodowej w Krakowie
}

\title{
Metody nauczania i środki dydaktyczne stosowane przez nauczycieli podstaw przedsiębiorczości - wyniki badań
}

Reforma strukturalna i programowa polskiego systemu edukacji na przełomie XX i XXI w. wprowadziła do wszystkich typów szkół ponadgimnazjalnych nowy przedmiot - podstawy przedsiębiorczości. Jego cele nadrzędne to wyposażenie uczniów w wiedzę i umiejętności z zakresu podstaw ekonomii i funkcjonowania różnego typu instytucji związanych z gospodarką rynkową oraz kształtowanie szeroko rozumianej postawy przedsiębiorczości, w tym otwartości i kreatywności w realizowaniu własnej kariery zawodowej.

Funkcjonowanie w polskiej szkole od 2003 r. nowego przedmiotu daje więc okazję do refleksji nad jego dydaktyczną realizacją, którą wyznaczają cele i zadania oraz osiagnięcia zapisane w podstawie programowej (Podstawa programowa ..., 2002) i przyjęte w autorskich programach nauczania (np. Makieła, Rachwał 2004). Podjęto zatem badania diagnostyczne, których celem było:

- ustalenie rodzaju i częstotliwości stosowania metod aktywizujących stosowanych w nauczaniu-uczeniu się podstaw przedsiębiorczości,

- poznanie opinii nauczycieli o stopniu wyposażenia szkół w środki dydaktyczne niezbędne do realizacji zadań związanych z nauczanym przedmiotem,

- ustalenie rodzajów środków dydaktycznych najczęściej wykorzystywanych na lekcjach podstaw przedsiębiorczości.

W badaniach posłużono się ankietą, która zawierała 20 pytań (15 zamkniętych i 5 otwartych). Badania przeprowadzono wśród 215 nauczycieli podstaw przedsiębiorczości wszystkich typów szkół ponadgimnazjalnych, na terenie ośmiu województw: lubelskiego, łódzkiego, małopolskiego, podkarpackiego, podlaskiego, śląskiego, wielkopolskiego i zachodniopomorskiego (tab. 1). W celu zapewnienia wiarygodności uzyskanych wyników odrzucono 20 ankiet niekompletnych.

$\mathrm{W}$ ankietowanej grupie blisko $1 \frac{1}{3}(29,2 \%)$ stanowili nauczyciele $\mathrm{z}$ ponad 20-letnim stażem pracy, a co piąty nauczyciel tego przedmiotu pracował w zawodzie nie dłużej niż pięć lat $(21,2 \%$ badanych). Nauczyciele w większości ukończyli studia wyższe w trybie stacjonarnym (dziennym) - 84,2\% osób, w tym 41,5\% - kierunki ekonomiczne. Spośród absolwentów kierunków nieekonomicznych dużą grupę stanowili geografowie, którzy dostrzegli szansę związaną z możliwością nauczania drugiego przedmiotu, bardzo bliskiego pod względem treści geografii społeczno-ekonomicznej (Piróg 2004, Rachwał 2004). Ponadto 47,6\% ankietowanych nauczycieli 
ukończyło studia podyplomowe z podstaw przedsiębiorczości, co jest niezbędne w przypadku absolwentów kierunków nieekonomicznych i zalecane w przypadku absolwentów kierunków ekonomicznych.

Tab. 1. Ankietowani nauczyciele podstaw przedsiębiorczości według typów szkół i wielkości ośrodków

\begin{tabular}{|c|c|c|c|c|c|c|}
\hline \multirow[t]{2}{*}{ Typ szkoły } & \multicolumn{2}{|c|}{ Liczba nauczycieli } & \multicolumn{4}{|c|}{ Liczba szkół w ośrodkach } \\
\hline & ogółem & $\%$ & $\begin{array}{l}\text { powyżej } \\
100 \text { tys. } \\
\text { mieszk. }\end{array}$ & $\begin{array}{c}\text { 50-100 tys. } \\
\text { mieszk. }\end{array}$ & $\begin{array}{l}\text { 20-50 tys. } \\
\text { mieszk. }\end{array}$ & $\begin{array}{c}\text { poniżej } \\
20 \text { tys. } \\
\text { mieszk. }\end{array}$ \\
\hline $\begin{array}{l}\text { Licea } \\
\text { ogólnokształcące } \\
(\mathrm{LO})\end{array}$ & 61 & 28,0 & 20 & 17 & 15 & 9 \\
\hline $\begin{array}{l}\text { Licea profilowane } \\
\text { (LP) }\end{array}$ & 11 & 5,2 & 3 & 5 & 3 & 0 \\
\hline $\begin{array}{l}\text { Technika } \\
\text { (T) }\end{array}$ & 28 & 13,0 & 5 & 6 & 15 & 2 \\
\hline $\begin{array}{l}\text { Zasadnicze szkoły } \\
\text { zawodowe } \\
(\mathrm{ZSZ})\end{array}$ & 5 & 2,3 & 2 & 2 & 1 & \\
\hline $\begin{array}{l}\text { Zespoły szkół: } \\
\text { - LO i LP } \\
\text { - LO, LP, T } \\
\text { - LP, T, ZSZ }\end{array}$ & $\begin{array}{l}19 \\
31 \\
40\end{array}$ & $\begin{array}{r}8,8 \\
14,5 \\
17,0\end{array}$ & $\begin{array}{r}9 \\
9 \\
15\end{array}$ & $\begin{array}{r}8 \\
9 \\
15\end{array}$ & $\begin{array}{r}2 \\
12 \\
7\end{array}$ & $\begin{array}{l}0 \\
1 \\
3\end{array}$ \\
\hline Razem & 195 & 100,0 & 63 & 62 & 55 & 15 \\
\hline
\end{tabular}

Źródło: opracowanie autorów na podstawie badań ankietowych.

Zapisane w Podstawie programowej... (2002) zadania, cele, treści i osiagnięcia wymagają od nauczyciela podstaw przedsiębiorczości stosowania nowatorskich rozwiązań metodycznych i wykorzystywania na lekcjach różnych środków dydaktycznych. Wyniki badań ankietowych dowodzą, że nauczyciele są przekonani o potrzebie stosowania metod aktywizujących. Metody aktywizujące stosuje często $44,1 \%$, a bardzo często $-12,8 \%$ badanych.

Analizując przestrzenne zróżnicowanie zjawiska, należy wskazać, że metody aktywizujące stosują bardzo często i często nauczyciele podstaw przedsiębiorczości z województw: łódzkiego, śląskiego, podlaskiego i zachodniopomorskiego. Stosunkowo duża grupa badanych wykorzystuje metody aktywizujące rzadko - 23,1\% lub tylko czasami - 10,0\% badanych (tab. 2). Wśród przyczyn tego stanu nauczyciele najczęściej podawali małą liczbę godzin w ramowym planie nauczania przeznaczoną na realizację podstaw przedsiębiorczości. Należy się zgodzić z opinią nauczycieli, że metody aktywizujące wymagają większego nakładu pracy (i nauczyciela, i ucznia) i są często czasochłonne. Jednak przyczyn niezbyt częstego stosowania metod aktywizujących na lekcjach z podstaw przedsiębiorczości należy także upatrywać w przygotowaniu dydaktycznym badanych nauczycieli (Tracz, Rachwał 2007). Więcej niż połowa ankietowanych nie podjęła żadnych form dokształcenia. 
Tab. 2. Częstotliwość stosowania metod aktywizujących przez nauczycieli podstaw przedsiębiorczości

\begin{tabular}{|l|r|r|}
\hline \multicolumn{1}{|c|}{ Częstotliwość stosowania metod aktywizujących } & \multicolumn{2}{|c|}{ Deklaracje } \\
\cline { 2 - 3 } & \multicolumn{1}{|c|}{ liczba } & \multicolumn{1}{c|}{ w\% } \\
\hline Bardzo często & 25 & 12,8 \\
\hline Często & 86 & 44,1 \\
\hline Czasami & 39 & 20,0 \\
\hline Rzadko & 44 & 23,1 \\
\hline Nigdy & 0 & 0,0 \\
\hline Razem & 195 & 100,0 \\
\hline
\end{tabular}

Źródło: opracowanie autorów na podstawie badań ankietowych.

Za metody, które najlepiej służą realizacji celów i zadań związanych z przedmiotem podstawy przedsiębiorczości, nauczyciele najczęściej uważają: gry dydaktyczne, metodę projektów i dyskusję. Wśród grupy gier dydaktycznych wymieniano często: burzę mózgów (50 wskazań), gry symulacyjne (20 wskazań), gry inscenizacyjne (14 wskazań), analizę SWOT (10 wskazań) i metaplan (8 wskazań). Dużą wartość dydaktyczną w nauczaniu przedmiotu mają metoda projektów (46 wskazań) i metody dyskusji (26 wskazań), szczególnie dyskusja „za i przeciw” i dyskusja panelowa.

Niestety, nauczyciele nie dostrzegają wartości dydaktycznej metod praktycznych, tylko 3 razy wskazano bowiem te metody $\mathrm{w}$ ankietach. Jest zatem duża potrzeba popularyzowania tych metod kształcenia w materiałach metodycznych, materiałach multimedialnych itp.

Jedną z podstawowych form nauczania podstaw przedsiębiorczości wskazaną przez ankietowanych jest praca w grupie i praca indywidualna. Niestety, około $40 \%$ ankietowanych nie rozróżnia znaczenia dwóch podstawowych terminów dydaktycznych: forma nauczania i metoda nauczania. Nauczyciele utożsamiają formę nauczania (np. praca w grupie) z metodą nauczania. Zapewne wynika to z zamiennego traktowania tych terminów w licznych opracowaniach metodycznych dla nauczycieli.

W dobie informacyjnego rozwoju cywilizacyjnego bardzo ważne staje się wykorzystanie w procesie dydaktycznym różnorodnych źródeł informacji, a w przypadku podstaw przedsiębiorczości - m.in. internetu, programów komputerowych i obudowy multimedialnej podręcznika. Wprawdzie komputer jest tylko narzędziem, ale bywa niezbędny do realizacji niektórych treści kształcenia, np. związanych z bankowością elektroniczną (Kulikowska, Krasnodębska 2007; Makieła, Rachwał 2007b; Osuch, Osuch 2007; Soczówka 2007).

Jak zatem szkoły są wyposażone w środki dydaktyczne służące realizacji zadań związanych z nauczaniem-uczeniem podstaw przedsiębiorczości? Które z nich nauczyciele wykorzystują najczęściej?

W ocenie 37,0\% ankietowanych szkoły są wyposażone dostatecznie w środki dydaktyczne służące realizacji zadań związanych z nauczaniem-uczeniem podstaw przedsiębiorczości. Prawie $1 / 3$ badanych $(27,1 \%)$ uznała, że szkoła jest źle wyposażona w środki dydaktyczne, a 26,6\% - że wyposażenie jest dobre (tab. 3).

Jeżeli rozpatrzymy przestrzenne wyposażenie szkół w środki dydaktyczne, to najgorsza jest sytuacja w województwach: zachodniopomorskim, lubelskim i śląskim. Ankietowani z tych województw najczęściej oceniali stań wyposażenia szkół w środki dydaktyczne jako zły. 
Tab. 3. Wyposażenie szkół w środki dydaktyczne do nauczania podstaw przedsiębiorczości w ocenie nauczycieli

\begin{tabular}{|l|r|r|}
\hline \multirow{2}{*}{ Ocena wyposażenia w środki dydaktyczne } & \multicolumn{2}{|c|}{ Deklaracje } \\
\cline { 2 - 3 } & \multicolumn{1}{|c|}{ liczba } & \multicolumn{1}{|c|}{ w \% } \\
\hline Bardzo dobra & 18 & 9,3 \\
\hline Dobra & 52 & 26,7 \\
\hline Dostateczna & 72 & 37,0 \\
\hline Zla & 53 & 27,0 \\
\hline Razem & 195 & 100,0 \\
\hline
\end{tabular}

Źródło: opracowanie autorów na podstawie badań ankietowych.

Badani nauczyciele podstaw przedsiębiorczości ze środków dydaktycznych wykorzystują najczęściej podręcznik (75\%), zeszyt ćwiczeń (55,8\%) i materiały statystyczne (39,4\%), znacznie rzadziej - multimedia: $34,8 \%$ respondentów korzysta z multimedialnych płyt CD-ROM dołączanych do podręczników (np. Makieła, Rachwał 2007a), 30\% wykorzystuje strony internetowe wybranych instytucji, a tylko 8,2\% korzysta z innych programów komputerowych tematycznie związanych z lekcją (tab. 4).

Tab. 4. Pomoce dydaktyczne najczęściej wykorzystywane przez nauczycieli na lekcjach podstaw przedsiębiorczości

\begin{tabular}{|l|r|r|}
\hline \multicolumn{1}{|c|}{ Pomoce dydaktyczne } & \multicolumn{2}{c|}{ Deklaracje } \\
\cline { 2 - 3 } & \multicolumn{1}{c|}{ liczba } & \multicolumn{1}{c|}{ w \% } \\
\hline Podręcznik & 147 & 75,0 \\
\hline Zeszyt ćwiczeń & 109 & 55,8 \\
\hline Poradnik metodyczny & 71 & 36,4 \\
\hline Słowniki & 41 & 21,0 \\
\hline Mulimedialne płyty CD-ROM dołączone do podręcznika & 68 & 34,8 \\
\hline Inne programy komputerowe & 16 & 8,2 \\
\hline Strony internetowe wybranych instytucji & 60 & 30,0 \\
\hline Dane statystyczne (roczniki) & 77 & 39,4 \\
\hline
\end{tabular}

Źródło: opracowanie autorów na podstawie badań ankietowych.

W badanej grupie nie dostrzeżono związku stażu pracy w zawodzie nauczyciela z rodzajem wykorzystywanych środków dydaktycznych, zarysowuje się natomiast zależność między oceną wyposażenia szkoły w środki dydaktyczne, a wykorzystywanymi na lekcjach pomocami dydaktycznymi. Na ogół nauczyciele oceniający nisko wyposażenie szkoły w środki dydaktyczne najczęściej w ankietach zaznaczali stosowanie pomocy dydaktycznych z grupy słownych: podręcznik, zeszyt ćwiczeń, słowniki.

Zaprezentowane wyniki badań diagnostycznych dostarczyły informacji, które wymagają weryfikacji. Należałoby podjąć badania obserwacyjne lekcji z podstaw przedsiębiorczości, aby zweryfikować deklarowane przez nauczycieli wykorzystanie metod aktywizujących ze stanem rzeczywistym. Wskazane jest również ustalenie podstawowego wyposażenia w środki dydaktyczne, niezbędnego do realizacji celów wyznaczonych w podstawie programowej. Przyczyniłoby się to do rozwoju teorii nauczania podstaw przedsiębiorczości i miałoby duże znaczenie dla praktyki szkolnej. 


\section{Literatura}

1. Kulikowska M., Krasnodębska B., 2007, Techniki multimedialne w nauczaniu podstaw przedsiębiorczości [w:] Rola przedsiębiorczości w aktywizacji gospodarczej, Z. Zioło, T. Rachwał (red.), seria: Przedsiębiorczość - Edukacja nr 3, Zakład Przedsiębiorczości i Gospodarki Przestrzennej IG AP w Krakowie, Wydawnictwo „Nowa Era”, Warszawa-Kraków, s. 308-316.

2. Makieła Z., Rachwał T., 2004, Podstawy przedsiębiorczości. Program nauczania dla liceum ogólnoksztatcacego, liceum profilowanego i technikum, Nowa Era, Warszawa.

3. Makieła Z., Rachwał T., 2007a, Podstawy przedsiębiorczości. Podręcznik dla liceum ogólnokształcacego, liceum profilowanego i technikum. Wyd. z CD-ROM, Nowa Era, Warszawa.

4. Makieła Z., Rachwał T., 2007b, Podstawy przedsiębiorczości. Poradnik metodyczny dla nauczycieli liceum ogólnokształcacego, liceum profilowanego i technikum. Wyd. z CD-ROM, Nowa Era, Warszawa.

5. Osuch E., Osuch W., 2007, Wybrane projekty edukacyjne w aktywizacji uczniów na lekcjach podstaw przedsiębiorczości [w:] Rola przedsiębiorczości w aktywizacji gospodarczej, Z. Zioło, T. Rachwał (red.), seria: Przedsiębiorczość - Edukacja nr 3, Zakład Przedsiębiorczości i Gospodarki Przestrzennej IG AP w Krakowie, Nowa Era, Warszawa-Kraków.

6. Piróg D., 2002, Ścieżka edukacyjna europejska i przedmiot podstawy przedsiębiorczości nowymi polami działania dla nauczycieli geografii [w:] Czynniki i bariery regionalnej wspótpracy transgranicznej - bilans dokonań, 50. Zjazd PTG Polańczyk - Rzeszów.

7. Podstawa programowa ksztatcenia ogólnego (dla liceum ogólnokształcacego, liceum profilowanego i technikum), Rozporządzenie Ministra Edukacji Narodowej i Sportu z dnia 26 lutego 2002 r., Dz.U. $\mathrm{Nr} 51$ z 9.05.2002 r., Warszawa.

8. Przedsiębiorczość a współczesne wyzwania cywilizacyjne, seria: Przedsiębiorczość - Edukacja nr 1, 2005, Zioło Z., Rachwał T. (red.), Zakład Przedsiębiorczości i Gospodarki Przestrzennej Instytutu Geografii AP w Krakowie, Wydawnictwo „Mi-Wa”, Kraków.

9. Rachwał T., 2004, Ksztaltowanie postaw przedsiębiorczych u uczniów wyzwaniem dla nauczycieli geografii [w]: Kształcenie i doskonalenie nauczycieli geografii w Polsce i krajach Unii Europejskiej $w$ drodze do jednoczacej się Europy, W. Osuch, D. Piróg (red.), Wydawnictwo Naukowe AP, Kraków.

10. Rola przedsiębiorczości w aktywizacji gospodarczej, seria: Przedsiębiorczość - Edukacja nr 3, 2007, Zioło Z., Rachwał T. (red.), Zakład Przedsiębiorczości i Gospodarki Przestrzennej Instytutu Geografii AP w Krakowie, Nowa Era, Warszawa-Kraków.

11. Rola przedsiębiorczości w podnoszeniu konkurencyjności społeczeństwa i gospodarki, seria: Przedsiębiorczość -Edukacja nr 2, 2006, Zioło Z., Rachwał T. (red.), Zakład Przedsiębiorczości i Gospodarki Przestrzennej Instytutu Geografii AP w Krakowie, Nowa Era, Warszawa-Kraków.

12. Soczówka M., 2007, Wykorzystanie technologii informacyjnej w nauczaniu-uczeniu się podstaw przedsiębiorczości [w:] Rola przedsiębiorczości w aktywizacji gospodarczej, Z. Zioło, T. Rachwał (red.), seria: Przedsiębiorczość - Edukacja nr 3, Zakład Przedsiębiorczości i Gospodarki Przestrzennej IG AP w Krakowie, Nowa Era, Warszawa-Kraków.

13. Tracz M., Rachwał T., 2007, Przedmiot postawy przedsiębiorczości-założenia realizacji a przygotowanie nauczycieli [w:] Rola przedsiębiorczości w aktywizacji gospodarczej, Z. Zioło, T. Rachwał (red.), seria: Przedsiębiorczość - Edukacja nr 3, Zakład Przedsiębiorczości i Gospodarki Przestrzennej Instytutu Geografii AP w Krakowie, Nowa Era, Warszawa-Kraków. 


\section{Teaching Methods and Didactic Means Used by the Teachers of Basis for Entrepreneurships. The Results of Researches}

After the reform of structure and agenda of Polish educational system at the end of twentieth century and at the beginning of twenty first century the new subject - the basis for entrepreneurships - was introduced. The existence of the subject in Polish schools since 2003 gives us a reflection on the didactic aspect appointed by the goals, the tasks, and the achievements recorded in the foundation for the curriculum as well as embraced by authorial curricula. The work presents the results of the research that aimed to:

- recognize the types and frequencies of incentive methods used in teaching and learning the basis for entrepreneurships,

- getting teacher's opinion on the instrument to perform the tasks imposed by the teaching of this subject,

- recognize which of the didactic means are the most often used on the basis for entrepreneurships classes. 